\title{
Examining the Validity of EKC in Western Africa: Different Pollutants Option
}

\author{
Adeyemi A. Ogundipe \\ Department of Economics and Development Studies \\ Covenant University, Ota, Nigeria \\ E-mail: ade.ogundipe@covenantuniversity.edu.ng
}

Tel: 234-816-192-7372Ｅ-mail: yemi_keke2001@yahoo.com

\begin{abstract}
Oluranti I. Olurinola
Department of Economics and Development Studies

Covenant University, Ota, Nigeria

John T. Odebiyi

Department of Economics and Development Studies

Covenant University, Ota, Nigeria
\end{abstract}

Received: February 10, 2015 Accepted: March 1, 2015

doi:10.5296/emsd.v4i2.7076 URL: http://dx.doi.org/10.5296/emsd.v4i2.7076

\begin{abstract}
The Environmental Kuznets Curve hypothesized pollution as a monotonic function of income which implies that as an economy develops, pollution level starts to increase but reaching a certain threshold the relation reverses. This study investigates the relationship between GDP per capita income and environmental degradation in Western Africa region using panel data analysis for the period 1990-2012. Our specific objective was to estimate EKC for four indicators of environmental quality such as $\mathrm{CO}_{2}$ emissions, Suspended particulate matter (PM10), lack of access to sanitation facilities and lack of access to safe drinking water; and establish whether these pollutants exhibit an inverted u-shape function. Likewise, we subject our estimated relationship to sensitivity checks to ensure robustness to changes in assumption
\end{abstract}


and estimation techniques, an aspect inherently lacking in most EKC literature. The study could not find an unambiguous evidence of an inverted u-shaped relationship for $\mathrm{CO}_{2}$ emissions while the other point source pollutants confirmed the EKC theory. We subjected our estimation to further robustness checks by ascertaining the statistical properties of the variables used and examined the long run sustainability; results were found to be consistent and suitable for policy inferences.

Keywords: Environmental degradation, Income, Panel cointegration, West Africa

Jel Classification: N5, Q5, C23, N17

\section{Introduction}

An important milestone in understanding the relationship between economic growth and the environment was laid during the second quinquennium of the 1980s, which recognizes the complementarities that exist between them, with an emphasis on the need to mainstream environmental concerns into the planning process in order to ensure sustainable development (Wced, 1987; Pearce and Warford, 1993). Grossman and Krueger (1991), in their path-breaking work on the potential environmental impacts of the North America Free Trade Agreement (NAFTA) has extended this milestone by providing seminal evidence in support of an inverted U-shaped relationship between economic growth (measured by increases in per capita income) and some indicators of environmental quality. This relationship is the so-called environmental Kuznets curve (EKC). The EKC phenomenon received further popularization by the World Bank (1992) in its development report.

According to Orubu et al., (2009) environmental degradation has serious adverse consequences on human welfare, mainly in terms of reduced well being and livelihood opportunities of individuals who are directly affected. Likewise, World Bank (1992) has highlighted some health and productivity effects for different categories of environmental degradation, including water pollution and water scarcity, air pollution, solid and hazardous wastes, soil degradation, deforestation, loss of biodiversity and atmospheric changes. Air pollution resulting mainly from suspended particulate matter and volatile organic compounds is known to cause chronic health problems among people who live close to industrial areas in urban centres. A large number of rural dwellers among, particularly women and children suffer from the adverse effects of indoor air, while vehicular and industrial activity also affect productivity as does the effect of acid rain on forests, crops, aquatic life and metal roofs of buildings. Water pollution is responsible for a number of water-borne diseases (Orubu, 2006). Solid and hazardous wastes also affect human health and productivity through the pollution of ground water resources, while soil degradation may increase the risk of reduced living standards among the vulnerable segments of the population who depend on farming for their living. Likewise, the energy crisis in Africa resulting in extensive usage of crude and dirty energy sources (as over 80 percent Sub-Saharan Africa dwellers depends on traditional biomass for energy sources) has contributed immensely to environmental degradation and exposure to health hazards which further deepens the cycle of poverty (Ogundipe and Akinyemi, 2014). 


\section{Ml Macrothink}

Environmental Management and Sustainable Development

ISSN 2164-7682

2015, Vol. 4, No. 2

It has also been observed that as a result of increasing economic activities, world consumption of fossil fuels such as oil, natural gas and coal, the amount of carbon dioxide in the atmosphere has increased substantially over its level over the past century (Sengupta, 1996; Ciegis, Stremikiene and Mativsaityte, 2007) stretching the natural greenhouse effect beyond its beneficial bound. And in effect has exposed the continents to a number of environmental problems, which include: soil erosion, desertification, deforestation, water and air pollution, relatively high carbon intensity, habitat loss and threatened wild life population, and poor sanitation facilities and practices (African Development Bank 2006).

In the words of Orubu et al., (2009) as coined from the Grossman and Krueger (1991) optimistic view, he opines that country's capacity to offset the degrading environmental impact of development tends to increase in the later stages of the growth process. It implies that during the initial stage of developmental process, when the typical economy is dominated by agriculture and allied activities, pollution intensity will be generally low ${ }^{1}$. But as the economy moves into heavy industry, pollution will tend to increase. Furthermore, as the economy shifts into high technology and services, pollution intensity will tend to fall. What is implied in this observation is that pollution intensity is likely to be increasing in countries at the lowest rung of the development ladder, up to the intermediate stage, before possibly declining after reaching a threshold level of income. If the EKC proposition holds true, then economic growth becomes an eventual means of achieving environmental improvement over time.

At this juncture, having situate the theoretical link in the pollution-income argument; a critical question remains why has some economies attained a considerable growth without an impressive decline in degradation, especially in resource abundant nations (a readily instance is Niger-Delta region in Nigeria). It therefore implies that though necessary to attain economic prosperity, growth alone is not sufficient for falling level of degradation but this must be accompanied by an effective abatement measures that promote investment in green and cleaner technologies and a sound industrial institutional regulations.

Our study assesses the preposition that, in the early stages of a country's economic development, economic growth actually serves to benefit the environment. In assessing the inverted U-shaped relationship between economic growth and environmental degradation; our study fall in line with Cole (1999); by indicating to what extent environmental damage can be decoupled from economic growth. Likewise, the study suggests the reasons why some environmental indicators appear to have improved with economic growth in western Africa economies, whilst other have worsened.

According to Stern (2003), the EKC is an essentially empirical phenomenon, but most of the EKC literature is econometrically weak. Very little studies has channel appropriate attention to econometric diagnosis statistics while minimal or no attention has been given to the statistical properties of the data used such as serial dependence or stochastic trends in time series and few test of model adequacy have been carried out or presented. An empirical study

\footnotetext{
${ }^{1}$ This corroborate the World Bank (2007) which stipulates that gas flaring and industrial emissions are the largest contributor to green house gases (GHGs) in the world.
} 


\section{Macrothink}

by Perman and Stern (2003); took these statistics into account with appropriate technique, and failed to validate the existence of EKC, instead obtained a more realistic view of the effect of economic growth and technological changes in environmental quality.

We intend to provide further clarification on the validity of EKC by accessing the stationary trends of the series used, a position also emphasized by Dasgupta et al., (2002); Perman and Stern, (2003). Though notion of EKC has been widely discussed and verified in literature, and a number of studies have arisen on the subject matter from the Africa economies; our re-examination tends to examine $i$. the validation of EKC for major pollutant in Western Africa ii. Ascertain the reliability of EKC in line with the claims of Stern (2003), as most empirical studies failed to account for the stationarity of series adopted, and iii. Conduct a robustness checks to validate the reliability of the econometrics analysis.

In this re-examination, we estimate EKC for four indicators of environmental quality that have featured in several studies; namely PM10, emissions of carbon dioxide, access to sanitation, and access to safe water for western Africa countries. To the best of our knowledge, extant studies have only considered $\mathrm{CO}_{2}$ emissions in Western Africa and for these studies, the problem of non-stationary series remain unsolved. Asides this contribution, our study provides a comparative frame and basis for charting the future direction of environmental policy in Africa countries.

\section{Stylized Facts}

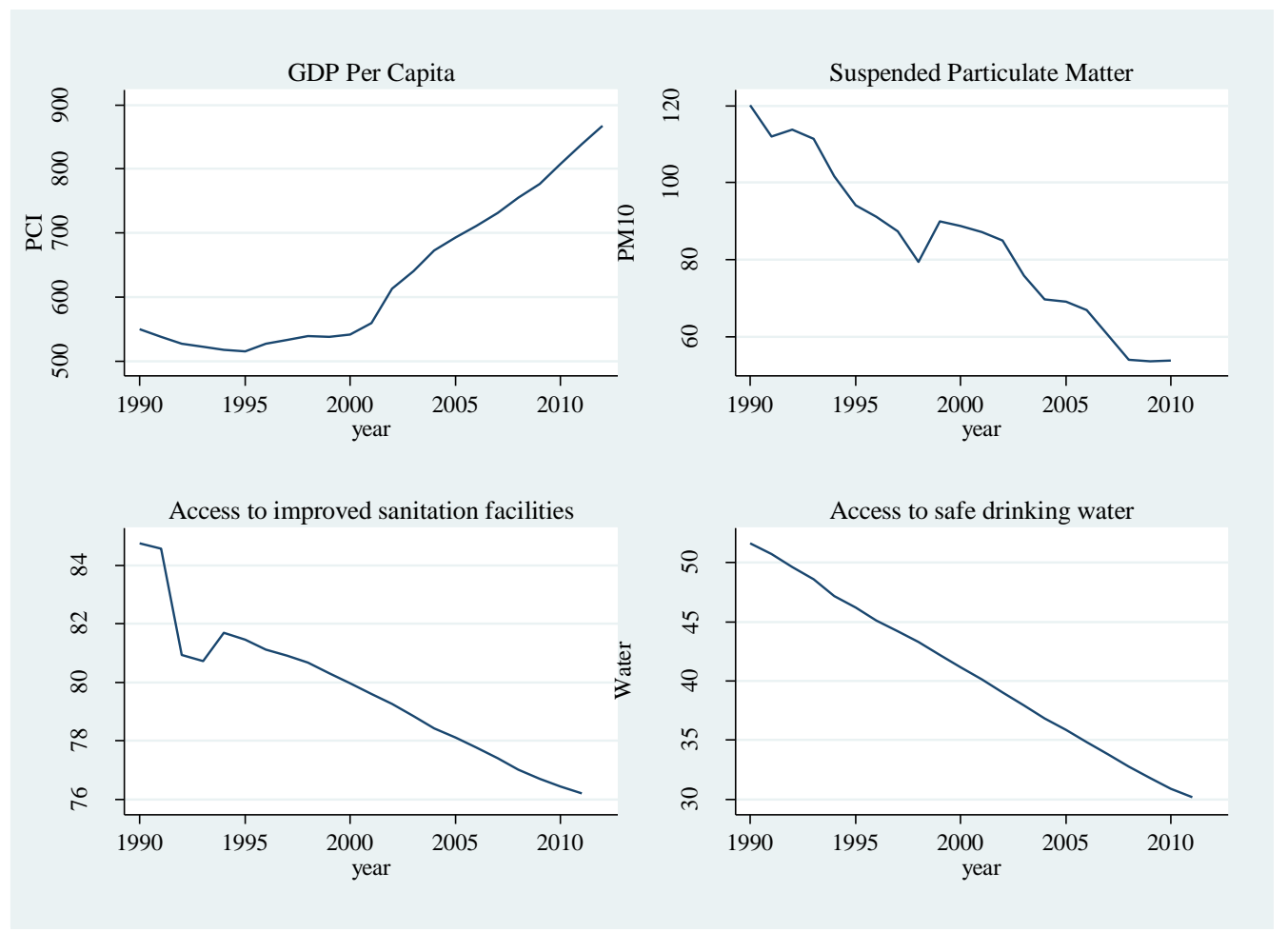

Figure 1. Trend of GDP Per Capita and Environmental Degradation in West Africa 


\section{Macrothink}

As shown in figure one above, the various pollutant observed as been falling considerably with rising per capita income, which validate the existence of EKC. Though, comparatively, measures of SPM for African countries are relatively high, compared to what obtains in a number of industrial countries. For example, SPM for Sweden, United Kingdom, United States, stood at 15, 17, and $27(\mu \mathrm{g} / \mathrm{m} 3)$ respectively, in 2003 (World Bank, 2003: 169). Compare these figures to those for Angola, Nigeria, and Sudan, measured at 112.8, 94.8, and 219 respectively for the year 2002. Most African countries are still at the intermediate stage of development, where industrial production and transportation is energy-intensive. As in other developing countries, indoor pollution from cooking fuels is also relatively high in African countries (Schwela, 2002); hence SPM levels tend to be high. It should also be noted that air pollution from particulate matter is higher when the primary fuel for power plants, industrial boilers, steel mills and domestic heating and cooking is based on coal and traditional biomass. In the developed countries, the use of crude energy source for fuel is rapidly giving way to cleaner forms of energy such as natural gas, solar energy and wind-driven systems; hence pollution from particulate matter in these countries is relatively lower. As incomes rise due to economic growth in African countries, air pollution from this source should decline, as households switch from cooking with firewood to gas, drive newer cars, and as production technologies become cleaner.

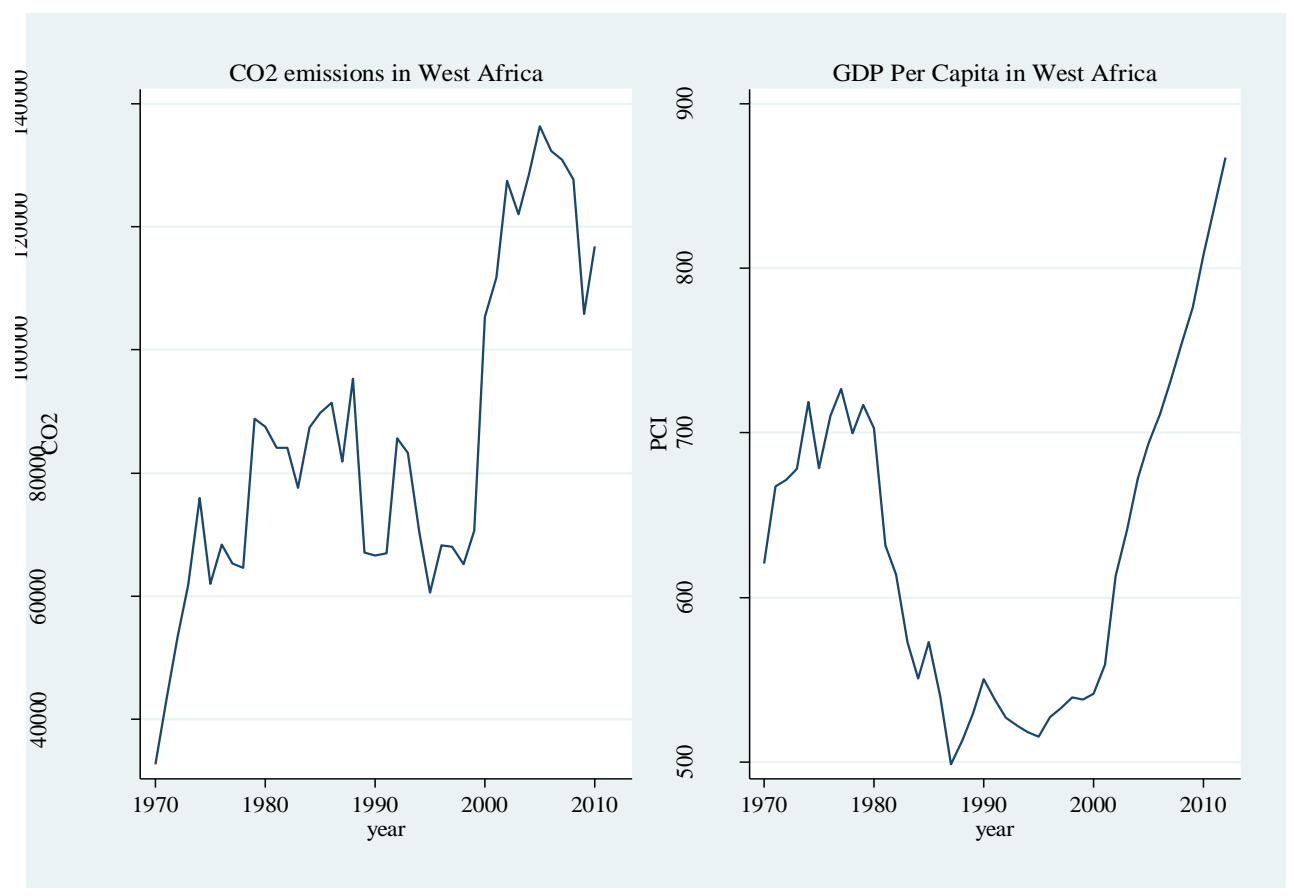

Figure 2. Trend of $\mathrm{CO}_{2}$ emissions (kt) and GDP Per Capita

Source: Computed from WDI, 2013; UNCTAD, 2013

As observed above, until 2000, $\mathrm{CO}_{2}$ emissions have been rising with falling income levels. Though the pattern of emissions seems to be quite unstable with incessant turns in the period 1970-2000; generally the trend featured an increasing function of income per capita. The pattern exhibited between $\mathrm{CO}_{2}$ and income appear not related to EKC features; this might not 
be unconnected to the fact that Africa's growth arises mainly from extractive commodities resulting in gas flaring and burning of fossil fuels which constitute the largest proportion of greenhouse gases. Likewise, the prevailing weak institutions and high elastic capture of economic resources has made economic rent accrued from crude oil and other extractive commodities skewed toward few proportion of the population. Subsequently, this has translated into gross neglect of the environment with no meaningful degradation abatement measures adopted. This trend persists until 2006 when $\mathrm{CO}_{2}$ emissions began to fall with rising income, this could have resulted from various domestic and international outcry for environmental abatement, the need to adopt cleaner technologies and the developing countries commitment under the Kyoto protocol treaty to reduce emissions.

Table 1. Trend and percentage change in GDP per capita and pollutants in West Africa

\begin{tabular}{c|l|c|l|c|l|c|c|l|c|l|c|}
\hline Year & \multicolumn{4}{c}{ PM10 } & \multicolumn{1}{l}{ Sanitation access } & \multicolumn{2}{c}{ Safe water access } & \multicolumn{2}{c}{ Carbon emission } & \multicolumn{2}{l}{ GDP Per Capita } \\
\hline & Trend & $\%$ & Trend & $\%$ & Trend & $\%$ & Trend & $\%$ & Trend & $\%$ \\
\hline 1990 & 120.15 & -6.71 & 84.76 & -0.21 & 51.63 & -1.78 & 0.29 & -1.39 & 537.57 & -2.33 \\
\hline 1995 & 94.13 & -21.66 & 81.46 & -3.89 & 46.21 & -10.50 & 0.29 & -2.75 & 515.27 & -6.38 \\
\hline 2000 & 88.74 & -26.15 & 71.96 & -5.66 & 41.15 & -20.29 & 0.26 & -12.68 & 541.51 & -1.61 \\
\hline 2005 & 69.26 & -42.36 & 78.12 & -7.83 & 35.87 & -30.53 & 0.30 & 0.12 & 693.57 & 26.02 \\
\hline 2010 & 54.03 & -55.03 & 76.43 & -9.82 & 30.89 & -40.16 & 0.31 & 4.48 & 808.02 & 46.81 \\
\hline
\end{tabular}

Source: Computed from WDI, 2013; UNCTAD, 2013

The table above presents the indicators of environmental degradation adopted in the study and compares their percent change with respect to changes in income level in West Africa. This is relevant in ascertaining environmental indicators and GDP per capita vary over time, and how the possibilities of EKC evolve in the region. Not until 2000, the percentage change in the indicators of environmental degradation and income featured a dwindling trend with steeper change in environmental indicators ${ }^{2}$. As the average income in the region rose drastically in 2005, the environmental indicators show a larger negative change except $\mathrm{CO}_{2}$ emissions which featured a positive change. For instance, as income increases by 26 percent in 2005, the share of West Africa population without access to sanitation facilities and safe drinking water reduced by 8 percent and 31 percent respectively while the concentration of suspended particles in the atmosphere reduced by 42 percent $^{3}$. In further validating the theoretical stand of EKC as it relates to pollution-income nexus; in 2010, the atmospheric suspended particles fell by 55 percent while the share of population without access to sanitation facilities and safe drinking water fell by 9 percent and 40 percent $^{4}$ respectively as income rises by 47 percent. Contrarily, carbon emissions rise by 5 percent $^{5}$ with observed

\footnotetext{
2 The change in reserves values of environmental degradation seems to be larger than that of income.

3 A possible indicator of access to better and cleaner cooking and lighting facilities

${ }^{4}$ Commitment to provision of borehole water facilities has recently gained more priority in developing Africa by national and international agencies. Also, households considers provision of safe drinking water as more essential than sanitation facilities

${ }^{5}$ in most cases, the process of generating growth leads to more emissions such as gas flaring and emissions from extractive activities. This is prominent in Africa as majority of Africa export, reaching about 99 percent in some economies are heavily
} 
increasing income in the same period.

Table 2. Share of West Africa's GDP per capita and pollutants to the Africa and World total

\begin{tabular}{|l|l|l|l|l|l|l|l|l|l|l|l|}
\hline year & \multicolumn{2}{c}{ Carbon emission } & \multicolumn{3}{c}{ PM10 } & \multicolumn{3}{c}{ Sanitation access } & \multicolumn{2}{c}{ Safe water access } & \multicolumn{2}{c|}{ GDP Per Capita } \\
\hline & Africa $^{a}$ & World & Africa $^{a}$ & World & Africa $^{a}$ & World & Africa $^{a}$ & World & Africa $^{a}$ & World \\
\hline 1980 & 23.36 & 0.45 & n.a & n.a & n.a & n.a & n.a & n.a & 76.9 & 13.9 \\
\hline 1985 & 19.03 & 0.45 & n.a & n.a & n.a & n.a & n.a & n.a & 68.9 & 10.8 \\
\hline 1990 & 14.41 & 0.30 & 102.18 & 153.72 & 113.84 & 161.77 & 107.41 & 216.19 & 68.94 & 9.51 \\
\hline 1995 & 12.41 & 0.26 & 103.67 & 138.20 & 110.13 & 169.22 & 90.3 & 223.11 & 70.79 & 8.63 \\
\hline 2000 & 20.16 & 0.42 & 113.79 & 140.60 & 110.34 & 181.93 & 74.80 & 235.34 & 71.84 & 8.22 \\
\hline 2005 & 21.5 & 0.46 & 117.28 & 132.20 & 109.94 & 195.01 & 61.21 & 250.06 & 80.50 & 9.72 \\
\hline 2010 & 16.50 & 0.35 & 130.21 & 132.16 & 109.84 & 208.03 & 49.77 & 268.03 & 83.40 & 10.75 \\
\hline
\end{tabular}

Source: Computed from WDI, 2013; UNCTAD, 2013

${ }^{a}$ means Sub-Saharan Africa, this option is considered due to absence of statistics for Africa region

n.a means not available

As seen in table 2, we intend to situate the position of West Africa in the Africa region and the world entirely with regards to environmental quality. From the statistics available, the west Africa's share of $\mathrm{CO}_{2}$ emissions in Africa spans between 23 percent and 13 percent; reaching 23.4 percent in 1980 and has been declining steadily until 2000 when it peak again to 20.2 percent and later fell to 16.5 percent in 2010. Likewise, the region's share in global emissions maintained the same falling trend. This similar pattern featured in GDP per capita; the region's share in Africa and world average has been falling consistently; this trend reverts in 2000 and 2005 for Africa and World respectively and has since risen steadily. Contrarily to the foregoing pattern, the region performed poorly when considering the atmospheric suspended particulate, sanitation access and access to safe water; with our statistics as contained in table 2 showing values far above Africa's and World's average.

Table 3. Correlation between GDP per Capital and Indicators of Environmental Quality

\begin{tabular}{|l|l|l|l|l|}
\hline S/N & Environmental Indicators & \multicolumn{1}{l}{ Correlation coefficients } & \multicolumn{1}{l}{ Prob. } & Significance \\
\hline 1 & PM10 & -0.8753 & 0.0000 & $1 \%$ \\
\hline 2 & $\mathrm{CO}_{2}$ & 0.4043 & 0.0691 & $6.9 \%$ \\
\hline 3 & Water Access & -0.9134 & 0.0000 & $1 \%$ \\
\hline 4 & Sanitation Access & -0.8538 & 0.0000 & $1 \%$ \\
\hline
\end{tabular}

Source: Computed using Stata 11.0

From our foregoing statistical analysis, it is obvious that all the indicators of environmental quality considered validate the EKC hypothesis except $\mathrm{CO}_{2}$ emissions. Also, the correlation coefficients between GDP per capita and the indicators portend similar attributes. The suspended particulate matter (PM10), share of population without access to safe water and 
sanitation facilities correlates negatively and significantly with GDP per capita implying that pollution falls consistently with increasing income. On the other side, $\mathrm{CO}_{2}$ emissions exhibit a positive and significant correlation with income.

\section{Review of Relevant Literature}

The concept of EKC is named after Kuznets (1985) who hypothesized income inequality first rises and then falls as economic development proceeds. According to Stern (2003) environmental Kuznets curve is a hypothesized relationship between various indicators of environmental degradation and income per capita. In the early stages of economic growth, degradation and pollution increase, but beyond some level of per capita (which will vary for different indicators) the trend reserves, so that at high-income levels economic growth leads to environmental improvement. In the words of Stern (2003), typically the logarithm of the indicator is modeled as a quadratic function of the logarithm of income.

Environmental degradation, first seen as mainly a problem of the rich nations and a side effect of industrial wealth, has become a survival issue for developing nations. It is part of the downward spiral of linked ecological and economic decline in which many of the poorest nations are trapped. The United Nations Report of the World Commission on Environment and Development in 1987 (Our Common Future) succinctly addressed the situation emphasizing that the relationship between development and environment has appear inseparable. Environment is where we all live and development is what we all do in attempting to improve our lot within the abode. What is needed now is a new era of economic growth-growth that is forceful and at the same time socially and environmentally sustainable. Humanity has the ability to make development sustainable to ensure that it meets the needs of the present without compromising the ability of future generations to meet their own needs. In order to achieve this, Dasgupta and Maler (1995) espoused strongly the role of local institutions by stating that the connection between environmental protection and civil and political rights is a close one. As a general rule, political and civil liberties are instrumentally powerful in protecting the environmental resource base, at least when compared with the absence of such liberties in countries run by authoritarian regimes.

The environmental Kuznets curve challenges the frequently advanced argument that increases in income lead inevitably to more pollution because more income implies more consumption, which in turn implies more pollution. Conceptually, an environmental Kuznets curve admits the possibility that there may be factors having the opposite effect of decreasing, rather than increasing, pollution. The combination of the two effects can thereby lead to pollution first increasing and then decreasing with increases in income (Carson, Jeon and McCubbin 1997).

The set of factors leading pollution to fall with income can be loosely classified into two groups. The first is that the richer countries tend to use different technology to produce goods that is less polluting per unit of output. Technology can be less polluting because it is explicitly designed for that purpose or simply because richer countries tend to use later vintage technology, which is often more efficient, particularly with respect to energy consumption. The second is that consumers will demand better environmental quality as they become wealthier (Carson, Jeon and McCubbin 1997). 


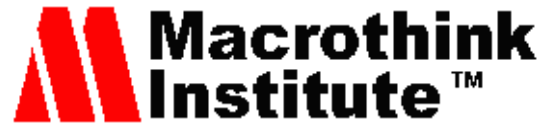

Likewise, Plassmann and Khanna (2010) emphasized that economists have suggested two primary explanations for this 'inverted u-shaped' relationship between pollution and income. The first relies on the idea that pollution first rises and then falls as an economy passes through different stages of development. The second explanation based on consumer preferences implies that accepting higher pollution as the price of higher income becomes increasingly unpalatable as household income increases. In addition, Barbier (1997) and Carson et al., (1997) have argued that other explanations like changes in technology, civil and political liberties, trade policy, and environmental policy are simply the vehicles that enable consumers to reveal their preferences for environmental quality.

The path breaking study of Grossman and Krueger (1991) on the potential environment impacts of NAFTA led to the emergence of EKC. Following the emergence, Shafik and Bandyopadhyay (1992) were the first to carry out a major study to validate the EKC hypothesis. Also, the World Commission on Environment and Development (1987) corroborate this strand by suggesting that economic growth is necessary in order for environmental quality to be maintained or improved.

The EKC concept became popularized by the World Bank's world development report (IBRD, 1982) which argued that: the view that greater economic activity inevitably hurts the environment is based on static assumptions about technology, tastes and environmental investments. As incomes rises the demand for improvements in environmental quality will increase, as will the resources available for investment. Others have expounded this position even more forcefully with Beckerman (1992) claiming that there is clear evidence that, although economic growth usually leads to environmental degradation in the early stages of the process, in the end the best and probably the only way to attain a decent environment in most countries is to become rich.

However, the EKC has never been shown to apply to all pollutants or environmental impacts and recent evidence (Dasgupta et al., 2002; Perman and Stern, 2003) challenges the nation of the EKC in general. Our study tends to situate EKC in West Africa using an appropriate econometric analysis. Stern (2003) posits that EKC is essentially empirical phenomenon but most of the EKC literature is econometrically weak. Likewise, Perman and Stern (2003) faulted the growing literature on validity of $\mathrm{EKC}$, as they neglected the statistical properties of the data used which often overlooked serial dependence or stochastic trends in time series and few tests of model adequacy have been carried out or presented. These controls and checks are quite pertinent, as rightly claimed by Perman and Stern (2003) "when we do take such statistics into account and use appropriate techniques we find that EKC does not exist"6

Since the seminar work by Grossman and Krueger (1991), the literature on the theory and empirics of EKC has been quite substantial (Herbaugh, Levinson and Nilson 2002; Khana 2002; Copeland and Taylor 2004; Cole et al 1997; Grossman and Krueger 1995; Selden and Song 1994; Holtz-Eakin and Selden 1992; Shafik 1992) while a number of these studies provided an empirical evidence validating EKC for different pollutants (Barbier, 1997;

\footnotetext{
${ }^{6}$ Perman and Stern (2003) instead found a more realistic view of the effect of economic growth and technological changes on environmental quality. It seems that most indicators of environmental degradation are monotonically rising in income though the income elasticity is less than one and is not a single function of income alone
} 
Osahbueon et al 2013) other have espoused a contrasting evidences (List and Gallet, 1999).

Shafik and Bandyopadhyay (1992) in their influential study estimated EKCs for ten different indicators using three different functional forms. Lack of clean water and lack of urban sanitation were found to decline uniformly with increasing income, and over time. The deforestation regressions showed no relation between income and deforestation. River quality tended to worsen with increasing income. Local air pollutant concentrations, however, conformed to the EKC hypothesis with turning points between $\$ 3000$ and $\$ 4000$. Finally, both municipal waste and carbon emissions per capita increased unambiguously with rising income.

Selden and Song (1994) estimated EKCs for four emissions series: $\mathrm{SO}_{2}, \mathrm{NO}_{\mathrm{x}}, \mathrm{SPM}$ and $\mathrm{CO}_{2}$ using longitudinal data from World Resources (WRI, 1991). The data are primarily from developed countries. The estimated turning points are all very high to some earlier studies ${ }^{7}$. For the fixed effects version of their model, the turning points are $\mathrm{SO}_{2}: \$ 10391 ; \mathrm{NO}_{\mathrm{x}}: 13383$; SPM: \$12275; and $\mathrm{CO}_{2}$ : $\$ 7114$. The study showed that the turning point for emissions was likely to be higher than that for ambient concentrations. In the initial stages of economic development, urban and industrial tends to become more concentrated in a smaller number of cities which also have rising central population densities with the reverse happening in the later stages of development. So it is possible for peak ambient pollution concentrations to fall as income rises even if total national emissions are rising (Stern et al.,1996).

Grossman and Krueger (1991) estimated EKCs for $\mathrm{SO}_{2}$, dark matter (fire smoke), and suspended particles (SPM). The turning points for $\mathrm{SO}_{2}$ and dark matter are at around $\$ 4000-5000$ while the concentration of suspended particles appeared to decline even at low income levels. According to Sten (2003), the emissions based studies have higher turning points than the concentrations based studies, though the empirical evidences by Kaufmann et al (1998) and Panayotou (1993) have unusual features which make them exceptional. Selden and Song (1994) and Cole et al (1997) adopted an emissions based study for OECD countries with estimated turning points of \$10391 and \$8232 respectively. Likewise, List and Gallet (1999) used fifty U.S States for the period 1929 to 1994 attaining a turning point of $\$ 22675$; the income per capita in their sample ranges from $\$ 1162$ to $\$ 22465$ measured in 1987 US dollars. The U.S economy tends to have a bigger range of income levels than found in OECD based panels. This hereby suggests that including more low income data points in the sample might yield a higher turning point. This was reflective in the study by Stern and Common (2001) which adopted an emissions database of the U.S Department of Energy covering a greater range of income levels and includes more data points than any of the other sulfur EKC studies with estimated turning point at over $\$ 100,000$ (Lefohn et al., 1999).

Empirical literature in Africa have obtained mixed evidences; indicators of environmental quality comprising lack of access to water, carbon emissions, deforestation and sanitation facilities have featured in few studies of EKC (Ogundipe et al., 2014; Osabuohien et al., 2014; Omotor and Orubu 2009; Bhattari and Hammig 2001). Ogundipe et al., (2014) could not established the EKC hypothesis in low income and upper middle groups while a feasible

${ }^{7}$ Grossman and Krueger (1991); Shafik and Bandyopadhyay (2012) 
turning point was reached in the lower middle income countries. Similarly, the empirical evidence from Omotor and Orubu (2009) established a relatively weak EKC for lack of access to sanitation while no evidence supported the existence of an EKC for lack of access to safe water. Though, Bhattari and Hammig (2001) adopted deforestation as a measure of environmental degradation, their study showed strong evidence of an EKC relationship between income and deforestation for Latin America, Africa and Asia. In the same spirit, Osabuohien et al., (2014) obtained a long-run functional relationship between $\mathrm{CO}_{2}$ emissions and income for fifty African countries using data from 1995-2010.

\section{Methodology and Data}

The model shall follow the specification proposed in most of the EKC studies and similarly evaluated by Chapman and Agra (1999), Stern (2003), Omotor and Orubu (2003), Al Sayed and Sek (2013) and Ogundipe, Alege and Ogundipe (2014) by adopting a regression procedure that assumes that levels of indicators are non-zero and non-negative. This restriction is applied by using a logarithmic dependent variable. A simple standard EKC regression model can be presented thus:

$$
\ln E D_{i t}=\alpha_{i}+\gamma_{t}+\beta_{1} \ln (G D P / P)_{i t}+\beta_{2}(\ln (G D P / P))_{i t}^{2}+\varepsilon_{i t}
$$

Where $E D_{i t}$ is environmental degradation, $(G D P / P)_{i t}$ is per capita GDP, $\alpha_{i}$ and $\gamma_{t}$ represent intercept parameter which vary across countries or regions $i$ and years $t$. Similarly, $\beta_{1}$ signifies the pollution-income relationship at the early stages of development and $\beta_{2}$ shows the realization (non-realization) of EKC hypothesis, the theory is validated when $\beta_{2}$ becomes negative and significant but inconsistent otherwise ${ }^{8}$. When $\beta_{2}$ becomes negative, it implies a possibility of turning point - the level at which environmental degradation begins to monotonically decrease with rising income. The equation of the turning point is given as: $\frac{G D P}{P}(T P)=\mathrm{e}^{-\left(\beta_{1} / 2 \beta_{2}\right)}$

The assumption is that though the level of emissions per capita may differ over countries at any particular income level the income elasticity is the same in all countries at a given income level. The time specific intercepts are intended to account for time varying omitted variables and stochastic shocks that are common to all countries.

The expanded EKC model for our study includes some control variables that are pertinent in influencing the pollution-income relationship in developing Africa. Theoretical and empirical literature have emphasized the effect of some control variables in influencing the nature and pattern of pollution-income relationship and their neglect could lead to omitted variable bias which has resulted into less desirability of a number of EKC studies.

$$
\begin{aligned}
& \ln E D_{i t}=\alpha_{i}+\gamma_{t}+\beta_{1} \ln (G D P / P)_{i t}+\beta_{2} \ln (G D P / P)_{i t}^{2}+\beta_{3} \operatorname{lnagrot}_{i t}+\beta_{4} \ln \text { trad }_{i t}+ \\
& \beta_{5} \text { lnlirt }_{i t}+\beta_{5} \operatorname{lninst}_{i t}+\varepsilon_{t}
\end{aligned}
$$

\footnotetext{
${ }^{8}$ According to Ogundipe, Alege and Ogundipe (2014), when $\beta_{2}$ is positive, environmental pressure rises with increasing income leading to a $U$-shaped relationship. Also, $\beta_{2}=0$ it indicates horizontal line, income therefore does not affect environmental pressure.
} 
Such that $E D_{i t}=\left\{\begin{array}{c}C O 2_{i t} \\ \operatorname{Sancs}_{i t} \\ S P M_{i t} \\ \text { Watr }_{i t}\end{array}\right\} ;$ a column vector of the indicators of environmental degradation.

$$
\begin{aligned}
& \operatorname{lnCO}_{i t}=\alpha_{i}+\gamma_{t}+\theta_{1} \ln (G D P / P)_{i t}+\theta_{2}(\ln (G D P / P))_{i t}^{2}+\theta_{3} \operatorname{lnagrot}_{i t}+\theta_{4} \text { lntrad }_{i t}+ \\
& \theta_{5} \operatorname{lnlirt}_{i t}+\theta_{6} \operatorname{lninst}_{i t}+\varepsilon_{t} \\
& \quad \operatorname{lnSancs}_{i t}=\alpha_{i}+\gamma_{t}+\varphi_{1} \ln (G D P / P)_{i t}+\varphi_{2}(\ln (G D P / P))_{i t}^{2}+\varphi_{3} \text {.nagrot }_{i t}+\varphi_{4} \operatorname{lntrad}_{i t}+ \\
& \varphi_{5} \operatorname{lnlirt}_{i t}+\varphi_{6} \operatorname{lninst}_{i t}+\mu_{t} \\
& \operatorname{lnSPM}_{i t}=\alpha_{i}+\gamma_{t}+\omega_{1} \ln (G D P / P)_{i t}+\omega_{2}(\ln (G D P / P))_{i t}^{2}+\omega_{3} \text { lnagrot }_{i t}+\omega_{4} \operatorname{lntrad}_{i t}+ \\
& \omega_{5} \operatorname{lnlirt}_{i t}+\omega_{6} \operatorname{lninst}_{i t}+v_{t} \\
& \operatorname{lnWatr}_{i t}=\alpha_{i}+\gamma_{t}+\chi_{1} \ln (G D P / P)_{i t}+\chi_{2}(\ln (G D P / P))_{i t}^{2}+\chi_{3} \operatorname{lnagrot}_{i t}+\chi_{4} \operatorname{lntrad}_{i t}+ \\
& \chi_{5} \operatorname{lnlirt}_{i t}+\chi_{6} \operatorname{lninst}_{i t}+\eta_{t}
\end{aligned}
$$

$\mathrm{CO}_{\text {it }}$ is carbon emission per capita measured in metric tons per capita, Sancs it is share of population without access to sanitation facilities, $S P M_{i t}$ is suspended particulate matter measured in micrograms per cubic meter, $W_{a t r}$ is the share of population without access to safe drinking water, agrot it $_{\text {it }}$ is agricultural output, trad $_{i t}$ captures trade intensity, lirt is literacy rate, inst $t_{i t}$ is an index of institution while $\varepsilon_{t}$ is the stochastic random term. The data for the empirical investigation are obtained from the World Development Indicators (2013) of the World Bank and the data market of Iceland database.

The available EKC studies have not provided a clear answer on the impact of trade on pollution ${ }^{9}$. Likewise, a number of theoretical strands claim that industrial expansion is the root cause of environmental degradation and should be restrained (Cole, 1999); why some economists see this as sufficient to generate the growth needed to mitigate environmental degradation (Lin and Liscow, 2011) ${ }^{10}$. On the other hand, others though agreed with the shape of the relationship between income and environmental degradation but disagree with the conclusion that by mitigating poverty, environmental quality would automatically improve. Instead they suggested that there are very important omitted variables and that what cleaned up the environment was not increasing income, but rather political institutions responding to public demand (Lomborg and Pope, 2003). Also, Deacon and Muller (2004) ${ }^{11}$ stressed the fact that a nation's political and institutional effectiveness determine the way its natural

\footnotetext{
${ }^{9}$ In our finite world the poor countries of today would be unable to find further countries from which to import resources intensive products as they themselves become wealthy. When the poorer countries apply similar levels of environmental regulation they would face the more difficult task of abating these activities rather than outsourcing them to other countries (Arrow et al., 1995; Stern et al., 1996).

${ }_{10}$ Their conclusion was consistent with EKC theory, according to them, the solution to environmental problem is to alleviate poverty

${ }^{11}$ Prominent among his observation hinged on the fact that when a country's natural resources or environmental services are capable of generating significant rents, but institutions of democratic governance and the rule of law are not well-established, corruption by government officials can encourage rent-seeking behavior, dissipating the benefits those resources or environmental services would otherwise confer.
} 


\section{Macrothink}

resource and environmental assets are used. Similarly, Khanna (2002) emphasized education as also a key factor in determining exposure to pollution or declining environmental quality, education as measured by literacy rate enhance preferences for cleaner environment.

In attempt to estimate our model using panel data approach, most studies estimated both fixed effects and random effects models. While the fixed effects model treats the $\alpha_{i}$ and $\gamma_{t}$ as regression parameters, the random effects model treats them as components of the random disturbance. If the effects $\alpha_{i}$ and $\gamma_{t}$ and the explanatory variables are correlated, then the random effects model cannot be estimated consistently (Mundlak, 1978; Hsiao, 1986). It implies that only the fixed effects model can be estimated consistently. The random effect model is estimated inconsistently due to correlation between the explanatory variables and the error components ${ }^{12}$. According to Hsiao (1986); assuming that there are no other statistical problems, the fixed effects model can be estimated consistently, but the estimated parameters are conditional on the country and time effects in the selected sample of data; which implies that they cannot be used to extrapolate to other samples of data ${ }^{13}$.

Likewise, in order to overcome the econometric weakness inherit in most EKC studies - as most of the studies are highly susceptible to changes in assumption about data and econometric techniques. There is therefore need to ascertain the robustness of our study by examining the statistical properties ${ }^{14}$ of our data and also examine the long run sustainability of our results by conducting the panel co-integration estimation. This hereby serves as a robustness check for our result and helps our study to overcome the diagnostic deficiency in a vast number of EKC empirical literature.

\footnotetext{
${ }^{12}$ Hausman (1978) test can be used to test for the inconsistency in the random effects estimate by comparing the fixed effects and random effects slope parameter

${ }^{13}$ Stern (2003) extensively espoused this argument by claiming that EKC estimated with fixed effect using only developed country data might have weak predictive power about the future behavior of developing countries. Substantial number of studies in EKC has neglected the implications of the failure of this orthogonality test; as many studies often compute the Hausman statistic and finding that the random effects model cannot be consistently estimated, they eventually estimated the fixed effects model.

14 The statistical properties of our data is examined using three panel unit root approaches, namely: Levin,Lim \& Chin; Lm, Persaran and Chin and Breitung.
} 


\section{Discussion of Results}

Table 4. Regression Results

\begin{tabular}{|c|c|c|c|c|c|c|c|c|c|c|c|c|}
\hline & \multicolumn{3}{|c|}{ Carbon emission } & \multicolumn{3}{|c|}{ PM10 } & \multicolumn{3}{|c|}{ Sanitation Access } & \multicolumn{3}{|c|}{ Water Access } \\
\hline & Ols & Fixed & random & Ols & Fixed & Random & Ols & Fixed & Random & ols & fixed & Random \\
\hline Lgdpk & $-7.982^{* *}$ & -7.646 & $-6.711^{*}$ & $4.030^{* *}$ & $8.211^{* * *}$ & $7.981^{* * *}$ & -0.569 & $1.673^{* * *}$ & $1.565^{* * *}$ & 0.934 & $4.360^{* *}$ & 2.056 \\
\hline & $(3.191)$ & $(4.786)$ & $(3.668)$ & (1.829) & $(1.509)$ & (1.391) & $(1.066)$ & $(0.561)$ & $(0.542)$ & (1.317) & (1.991) & $(1.597)$ \\
\hline lgdpk2 & $0.738^{* * *}$ & $0.707^{*}$ & $0.639^{* *}$ & $-0.325^{* *}$ & $-0.721^{* * * *}$ & $-0.694^{* * * *}$ & 0.0389 & $-0.146^{* * *}$ & $-0.137^{* * *}$ & -0.0847 & $-0.429^{* *}$ & -0.220 \\
\hline & $(0.261)$ & $(0.408)$ & $(0.311)$ & $(0.149)$ & $(0.121)$ & $(0.113)$ & $(0.0873)$ & $(0.0478)$ & $(0.0462)$ & $(0.108)$ & $(0.170)$ & $(0.136)$ \\
\hline lagrot & $-0.309^{*}$ & $0.791^{* * * *}$ & $0.716^{* * *}$ & ---- & ---- & ---- & 0.260 & 0.0160 & 0.0193 & $0.334^{* * * *}$ & $-0.192^{* * * *}$ & -0.102 \\
\hline & $(0.172)$ & $(0.167)$ & $(0.150)$ & & & & $(0.0578)$ & $(0.0196)$ & $(0.0191)$ & $(0.0714)$ & $(0.0695)$ & $(0.0648)$ \\
\hline Ltrad & $0.911^{\text {*** }}$ & 0.150 & 0.175 & 0.162 & 0.0333 & 0.0422 & 0.0562 & 0.00207 & 0.00187 & $0.600^{* * *}$ & 0.0336 & 0.0407 \\
\hline & $(0.194)$ & $(0.106)$ & $(0.107)$ & $(0.105)$ & $(0.0641)$ & $(0.0643)$ & $(0.0677)$ & $(0.0135)$ & $(0.0133)$ & $(0.0836)$ & $(0.0479)$ & $(0.0503)$ \\
\hline Llirt & 0.107 & $-0.175^{* *}$ & $-0.174^{* * *}$ & $-0.803^{* * * *}$ & $-0.406^{* * * *}$ & $-0.436^{* * * *}$ & -0.0585 & $-0.0606^{* * * *}$ & $-0.0608^{* * * *}$ & -0.612 & $-0.311^{* * *}$ & $-0.351^{\text {**** }}$ \\
\hline & $(0.110)$ & $(0.0877)$ & $(0.0825)$ & $(0.0595)$ & $(0.0434)$ & $(0.0417)$ & $(0.0369)$ & $(0.0104)$ & $(0.0102)$ & $(0.0456)$ & $(0.0369)$ & $(0.0361)$ \\
\hline Linst & 0.317 & 0.107 & 0.141 & -0.00164 & $0.182^{* * * *}$ & $0.173^{* * * *}$ & -0.0678 & 0.0135 & 0.0127 & -0.0341 & 0.0368 & 0.0148 \\
\hline & $(0.251)$ & $(0.122)$ & $(0.121)$ & $(0.135)$ & $(0.0657)$ & $(0.0660)$ & $(0.0840)$ & $(0.0144)$ & $(0.0141)$ & $(0.104)$ & $(0.0510)$ & $(0.0526)$ \\
\hline constant & $16.32^{*}$ & 15.73 & 12.61 & -6.290 & $-17.79^{* * * *}$ & $-17.37^{* * * *}$ & 5.493 & -0.279 & 0.0309 & -0.615 & -5.466 & 0.552 \\
\hline & (9.597) & (13.81) & $(10.65)$ & $(5.527)$ & $(4.651)$ & $(4.253)$ & (3.207) & (1.619) & (1.564) & $(3.963)$ & $(5.747)$ & $(4.635)$ \\
\hline Hausman & & $24.15^{* * *}$ & & & $22.79^{* * * *}$ & & & & 0.72 & & $24.55^{\text {** }}$ & \\
\hline Observation & 137 & 137 & 137 & 171 & 171 & 171 & 135 & 135 & 135 & 135 & 135 & 135 \\
\hline R-squared & 0.628 & 0.233 & & 0.611 & 0.757 & & 0.282 & 0.590 & & 0.647 & 0.772 & \\
\hline No. of id & & 14 & 14 & & 15 & 15 & & 14 & 14 & & 14 & 14 \\
\hline
\end{tabular}

Computed using Stata 11.0

${ }^{* * *}$ significance at $1 \%,{ }^{* *}$ significance at $5 \%,{ }^{*}$ significance at $10 \%$

Table 5. Turning Points of Environmental Pollutants

\begin{tabular}{|l|l|l|l|}
\hline S/N & Environmental Indicators & Turning Point $\mathbf{( \$ )}$ & Turning Point in LCU (\#) \\
\hline 1 & PM10 & $\$ 297.14$ & $51,999.5$ \\
\hline 2 & $\mathrm{CO}_{2}$ & $\$ 233.05$ & $39,033.8$ \\
\hline 3 & Water Access & $\$ 161.03$ & $28,180.5$ \\
\hline 4 & Sanitation Access & $\$ 302.38$ & $52,916.5$ \\
\hline
\end{tabular}

Computed using Stata 11.0 
The estimation procedure begins by estimating the traditional pooled OLS and later proceed to the fixed and random effect. Using the hausman statistic, we obtain the fixed effect specification as most suitable, consistent and reliable for $\mathrm{CO}_{2}$ emissions, suspended particulate matter (SPM) and water access (watr) models while the random specification was adopted for sanitation access model. As illustrated in table 4, our choice of efficient specification centered on the significance of hausman test statistic which were 24.15, 22.79 and 24.55 for $\mathrm{CO}_{2}$, SPM and WATR respectively while test statistic of 0.72 for SANCS was not significant.

The $\mathrm{CO}_{2}$ emissions failed to validate the EKC hypothesis for the traditional ols estimation and for both random and fixed effects specifications. At the early stage of development, our result indicates a significant negative relationship between emissions and income ${ }^{15}$, while the coefficient of the income squared $\left(l g d p k^{2}\right)$ though significant but was positive indicating that $\mathrm{CO}_{2}$ emissions exhibits a rising function of income with no feasible turning point attained. As emphasized earlier, this might not be unconnected to the fact that the growth process of Africa economies is dirty and pollution induced as majority of the economies exports primary commodity goods. In addition, literacy rate and agricultural output exert an inverse and positive statistical significance influence on emissions respectively. This is consistent with empirical stands from Shafik (1994), Khanna (2002), Orubu and Awopegba (2009), Galeotti et al., (2006), Coondoo and Dinda (2008) and Alege and Ogundipe (2013); it indeed a general consensus that as people become more educated, their awareness and desire for cleaner environments rises. Secondly, because of the dwindling prices for non-oil commodities as a result of demand shocks and commodity financialisation, majority of non-oil commodity dependent Africa economies are running to stay still in their export volume which posed a greater challenge for the environment.

On the other hand, empirical evidences from suspended particulate matter (SPM), share of population without sanitation access (sancs) and water access (watr) confirmed the existence of EKC in West Africa. This corroborates the empirical studies by Shafik (1994); Grossman (1993); Panayotou (1993); Seldon and Song (1994); Orubu et al., (2009); Lee, Chin and Sun (2010) and Shafik and Bandhopadhyay (1992) which all validated the EKC hypothesis for PM10, water and sanitation access; but our result differs from that obtained by Grossman and Krueger (1991). The spm ${ }^{16}$, sancs and watr models have an inverted U-shaped for the fixed effect specification, though sancs model was only consistent for random effect specification. Unlike, $\mathrm{CO}_{2}$ emissions, there exists a positive relationship (spm, sancs, watr) and income at the early stage of development, that is, pollution rises and income increases while the significant negative coefficient of the income squared $\left(l g d p k^{2}\right)$ indicate the presence of turning points ${ }^{17}$ hereby confirming EKC hypothesis. Moreover, literacy rate was significant

\footnotetext{
15 This is captured by the coefficient of GDP per capita income (lgdpk) which is given as $-7.982,-7.646$ and -6.711 for the traditional ols, fixed effect and random effect specifications respectively. This is likely to have resulted from the fact that income is skewed in developing Africa economies

${ }^{16}$ Suspended particulate matter has an inverted u-shaped curve for all the three specification, that is, the traditional ols, fixed and random effects

17 It indicates the point (s) where pollution begins to fall with rising income. The point is characterized by a significant negative coefficient of the income squared and indicates the validation of Environmental Kuznets Curve hypothesis. This points varies with different pollutant, it can be capture as an income level where environment starts to improve
} 


\section{Macrothink}

in our entire model, implying that education is necessary and effective in mitigating the level of environmental pollution and could help most especially in the nature and type of cooking and lighting sources, bush burning practices and proper waste disposal awareness. Similarly, institutions play a critical role, from the empirical analysis, poor institution exacerbate the level of environmental degradation.

From our estimated turning points in table 5, income level at which households are willing to reduce their exposure to pollution depends on the nature of pollution. We found an inverted u-shaped relationship between household income and PM10 with a peak at about \$297; water and sanitation access reached a peak at $\$ 161$ and $\$ 302$ respectively ${ }^{18}$. The turning points are relatively lower in West Africa when compared with those from advanced world ${ }^{19}$; for instance, Shafik (1994), Grossman (1993) Seldon and Song (1994) found turning point for PM10 as $\$ 3300, \$ 1600$ and $\$ 9800$ respectively. The low turning point for Western Africa may not unlikely due to the low per capita income in the region, Orubu et al., (2009) also obtained $\$ 280$ for PM10 in Africa. The validation of the EKC hypothesis the pollutant can be hinged on the fact that PM10, water and sanitation access are point-source pollutant, and it is fairly straightforward and relatively inexpensive to reduce exposure to these pollutants by relocating, without necessarily reducing global emissions.

\footnotetext{
18 The local currency equivalents of income turning points for PM10, water and sanitation access are \#51, 999.5, \#28, 180.5 and \#52, 916.5 respectively. The value for PM10 and sanitation access is expected to be higher than water access due to the recent domestic and international provisions of safe drinking water. Similarly, it's relatively cheaper to afford safe drinking water than to relocate.

${ }^{19}$ Lee, Chin and Sun (2010) obtained turning point for water pollution as \$13958 and Shafik and Bandhopadhyay (1992) obtained turning point for local air pollutant as $\$ 3000$
} 
Table 6. Panel Root Units

\begin{tabular}{|c|c|c|c|c|c|c|c|c|c|}
\hline & \multicolumn{3}{|c|}{ Levin,Lim \& Chin } & \multicolumn{3}{|c|}{ Lm, Persaran \& Shin } & \multicolumn{3}{|c|}{ Breitung } \\
\hline & Level & $1^{s t}$ diff & Order & level & $1^{s t}$ diff & order & Level & $I^{\text {st }}$ diff & order \\
\hline$l c o 2 m$ & $\begin{array}{l}0.2786 \\
(0.6097)\end{array}$ & $\begin{array}{l}-8.3532^{* * *} \\
(0.0000)\end{array}$ & $\mathrm{I}(1)$ & $\begin{array}{l}1.1973 \\
(0.8844)\end{array}$ & $\begin{array}{l}-7.6567^{* * *} \\
(0.0000)\end{array}$ & $\mathrm{I}(1)$ & $\begin{array}{l}-0.3113 \\
(0.3778)\end{array}$ & $\begin{array}{l}-3.7661^{\text {*** }} \\
(0.0001)\end{array}$ & $\mathrm{I}(1)$ \\
\hline$L g d p k$ & $\begin{array}{l}2.8883 \\
(0.9981)\end{array}$ & $\begin{array}{l}-4.3491^{* * *} \\
(0.0000)\end{array}$ & $\mathrm{I}(1)$ & $\begin{array}{l}2.9792 \\
(0.9986)\end{array}$ & $\begin{array}{l}-5.2522^{* * *} \\
(0.0000)\end{array}$ & $\mathrm{I}(1)$ & $\begin{array}{l}2.4291 \\
(0.9924)\end{array}$ & $\begin{array}{l}-1.5894^{*} \\
(0.0560)\end{array}$ & $\mathrm{I}(1)$ \\
\hline $\operatorname{lgdpk2}$ & $\begin{array}{l}2.9833 \\
(0.9986)\end{array}$ & $\begin{array}{l}-4.3447^{* * *} \\
(0.0000)\end{array}$ & $\mathrm{I}(1)$ & $\begin{array}{l}3.0990 \\
(0.9990)\end{array}$ & $\begin{array}{l}-5.2018^{* * * *} \\
(0.0000)\end{array}$ & $\mathrm{I}(1)$ & $\begin{array}{l}2.5847 \\
(0.9951)\end{array}$ & $\begin{array}{l}-1.4014^{*} \\
(0.0805)\end{array}$ & $\mathrm{I}(1)$ \\
\hline lagrot & $\begin{array}{l}-2.3954^{* * *} \\
(0.0083)\end{array}$ & $\begin{array}{l}-8.3880^{* * *} \\
(0.0000)\end{array}$ & $\mathrm{I}(1)$ & $\begin{array}{l}-1.3566^{*} \\
(0.0875)\end{array}$ & $\begin{array}{l}-7.3653^{* * *} \\
(0.0000)\end{array}$ & $\mathrm{I}(1)$ & $\begin{array}{l}-0.6605 \\
(0.2545)\end{array}$ & $\begin{array}{l}-3.2049^{* * *} \\
(0.0007)\end{array}$ & $\mathrm{I}(1)$ \\
\hline lpodn & $\begin{array}{l}-1.2062 \\
(0.1139)\end{array}$ & $\begin{array}{l}-11.2475^{* * *} \\
(0.0000)\end{array}$ & $\mathrm{I}(1)$ & $\begin{array}{l}7.3690 \\
(1.0000)\end{array}$ & $\begin{array}{l}-15.0068^{* * *} \\
(0.0000)\end{array}$ & $\mathrm{I}(1)$ & $\begin{array}{l}3.9729 \\
(1.0000)\end{array}$ & $\begin{array}{l}0.96087 \\
(0.8317)\end{array}$ & $\mathrm{I}(0)$ \\
\hline lsnacs & $\begin{array}{l}0.0244 \\
(0.5097)\end{array}$ & $\begin{array}{l}-1.8024^{* *} \\
(0.0357)\end{array}$ & $\mathrm{I}(1)$ & $\begin{array}{l}3.9157 \\
(1.0000)\end{array}$ & $\begin{array}{l}-3.5919^{* * *} \\
(0.0002)\end{array}$ & $\mathrm{I}(1)$ & $\begin{array}{l}-1.7700^{* *} \\
(0.0384)\end{array}$ & $\begin{array}{l}1.2462 \\
(0.8937)\end{array}$ & $\mathrm{I}(0)$ \\
\hline lspm & $\begin{array}{l}-2.4570^{* * *} \\
(0.0070)\end{array}$ & $\begin{array}{l}-9.4275^{* * *} \\
(0.0000)\end{array}$ & $\mathrm{I}(1)$ & $\begin{array}{l}-0.1388 \\
(0.4448)\end{array}$ & $\begin{array}{l}-8.0775^{* * *} \\
(0.0000)\end{array}$ & $\mathrm{I}(1)$ & $\begin{array}{l}-2.3214 \\
(0.0101)\end{array}$ & $\begin{array}{l}-7.9819^{* * *} \\
(0.0000)\end{array}$ & $\mathrm{I}(1)$ \\
\hline ltrad & $\begin{array}{l}-1.8370 \\
(0.0331)\end{array}$ & $\begin{array}{l}-6.5737^{* * *} \\
(0.0000)\end{array}$ & $\mathrm{I}(1)$ & $\begin{array}{l}-0.8290 \\
(0.2035)\end{array}$ & $\begin{array}{l}-6.1785^{* * *} \\
(0.0000)\end{array}$ & $\mathrm{I}(1)$ & $\begin{array}{l}0.0448 \\
(0.5179)\end{array}$ & $\begin{array}{l}-3.9621^{* * * *} \\
(0.0000)\end{array}$ & $\mathrm{I}(1)$ \\
\hline lwatr & $\begin{array}{l}-3.9183^{* * *} \\
(0.0000)\end{array}$ & $\begin{array}{l}9.1353^{* * *} \\
(1.00000)\end{array}$ & $\mathrm{I}(1)$ & $\begin{array}{l}3.8365 \\
(0.9999)\end{array}$ & $\begin{array}{l}-3.0223^{* * *} \\
(0.0013)\end{array}$ & $\mathrm{I}(1)$ & $\begin{array}{l}-2.8364^{* *} \\
(0.0023)\end{array}$ & $\begin{array}{l}3.0676 \\
(0.9989)\end{array}$ & $\mathrm{I}(0)$ \\
\hline llirt & $\begin{array}{l}-2.1090^{* *} \\
(0.0175)\end{array}$ & $\begin{array}{l}-3.9317^{* * *} \\
(0.0000)\end{array}$ & $\mathrm{I}(1)$ & $\begin{array}{l}3.5852 \\
(0.9998)\end{array}$ & $\begin{array}{l}-2.7137^{* * *} \\
(0.0033)\end{array}$ & $\mathrm{I}(1)$ & $\begin{array}{l}1.7712 \\
(0.9617)\end{array}$ & $\begin{array}{l}-1.6314^{* *} \\
(0.0514)\end{array}$ & $\mathrm{I}(1)$ \\
\hline linst & $\begin{array}{l}-0.6909 \\
(0.2448)\end{array}$ & $\begin{array}{l}-3.2156^{* * *} \\
(0.0000)\end{array}$ & $\mathrm{I}(1)$ & $\begin{array}{l}-3.0740^{* *} \\
(0.0011)\end{array}$ & $\begin{array}{l}-45.1408^{* * *} \\
(0.0000)\end{array}$ & $\mathrm{I}(1)$ & $\begin{array}{l}-2.6013^{* *} \\
(0.0046)\end{array}$ & $\begin{array}{l}-21.9011^{* * *} \\
(0.0000)\end{array}$ & $\mathrm{I}(1)$ \\
\hline
\end{tabular}

Source: computed using e-views 7.0

${ }^{* * *}$ significance at $1 \%,{ }^{* *}$ significance at $5 \%,{ }^{*}$ significance at $10 \%$

In attempt to ensure robustness of both our descriptive and empirical claims in the earlier section, and to fill a major gap in the EKC literature; our study hereby proceeds to ascertain if the result obtained as regards the pollution-income nexus in West Africa is sustainable overtime. Inability to ascertain the long-run sustainability of EKC evidences has erstwhile been a major empirical flop in EKC studies and has progressively results in the vast number of mixed evidences in literature. In the words of Perman and Stern (2003), Coondoo and Dinda (2002) if the EKC regressions do not cointegrate then the estimates will be spurious, very few studies have reported any diagnostic statistics for integration of the variables or cointegration of the regressions and so it's unclear what we can infer from the majority of EKC studies.

This section hereby examines the stationarity property of the variables in the system to ensure that the variables converge in the long run. This test is carried out using three statistics, namely; Levin, Lim and Chin (LLC); Lm, Pesaran and Shin (IPS) and Breitung. As show in 
the table 5, agricultural output (lagrot) was stationary at order zero I(0) for LLC and LPS. Likewise, suspenden particulate matter (spm) and access to safe drinking water (lwatr) were stationary at order I(0) for LLC while sanitation access (lsancs) and water access (lwatr) were stationary at $\mathrm{I}(0)$ for Breitung. Similarly, institution (linst) became stationary at $\mathrm{I}(0)$ for both LPS and breitung. The remaining variables were stationary at I(I) processes under LLC, LPS and Breitung at 5 percent significance level.

Table 7. Panel Co-integration: Kao Residual Co-integration test

\begin{tabular}{|l|l|l|l|}
\hline \multicolumn{4}{|l|}{ Carbon emission $\left(\mathrm{CO}_{2}\right)$} \\
\hline ADF $t$-stat & Prob. & Residual variance & HAC variance \\
\hline-0.8406 & 0.2003 & 0.02568 & 0.01202 \\
\hline PM10 & 0.004691 \\
\hline-4.2712 & 0.0000 & 0.010745 & 0.0000308 \\
\hline Sanitation access & \\
\hline 2.7108 & 0.0034 & 0.0000415 & 0.0000137 \\
\hline Water access & 0.0001 & 0.0000136 & \\
\hline 3.7304 & &
\end{tabular}

Source: computed using e-views 7.0

This re-examination provided a major leap to extant studies in Africa, as majority of the EKC studies failed to report cointegration statistics that might tell us if omitted variables bias is likely to be a problem or not; it becomes difficult to test the strength of additional explanatory variables. Therefore, it is not really clear what we can infer from the body of those works. According to Stern (2003), the only robust conclusions from the EKC literature appear to be that concentrations of pollutants may decline from middle income levels while emissions tend to be monotonic in income; that is, emissions may decrease overtime in countries at many different levels of development.

The panel co-integration results was consistent with our foregoing claims, as seen in table 6, the significance of the Kao residual value for suspended particulate matter (PM10), sanitation access (sancs) and water access (watl) model signifies long run convergence, implying that the models are efficient and consistent over time. On the other hand, the panel kao residual test failed to establish a long-run convergence for $\mathrm{CO}_{2}$ emissions model ${ }^{20}$. The non-convergence also indicates a refutation of the EKC hypothesis in West Africa region for $\mathrm{CO}_{2}$, while the hypothesis was validated for suspended particulate matter, sanitation and water access. This stand confirms our estimation result as contained in table 4 and hereby implies that our result is consistent and can be relied upon for the purpose of forecasting and policy inferences.

\section{Conclusion and Recommendation}

This study attempts to re-examine the pollution-income nexus in West Africa considering

\footnotetext{
${ }^{20}$ The probability of the Kao residual panel cointegration test stood at 20 percent which is far greater than the acceptable 5 percent significance level.
} 
different pollutants, which are $\mathrm{CO}_{2}$ emissions, suspended particulate matter (SPM), share of population without water (watr) and share of population without access to sanitation (sancs). The study validated the EKC theory for PM10, water and sanitation access while $\mathrm{CO}_{2}$ emissions failed to confirm the hypothesis. Likewise, PM10 and sanitation access reached their peak at \$297 and \$302 respectively while turning point attained for $\mathrm{CO}_{2}$ emissions could not be relied on since its coefficient was positive and not significant.

Though a negative relationship exist between household income and pollution at the initial stages of development ${ }^{21}$; the study does not find an unambiguous evidence supporting an inverted $\mathrm{u}$ shaped relationship for the non point-source pollutant; this is consistent with empirical evidences suggesting that the private abatement cost for $\mathrm{CO}_{2}$ pollution are relatively high. Even in a country with one of the highest incomes in the world, household income has not yet reached the level beyond which pollution-income relationship for such pollutant becomes negative.

In order to ensure consistency, we subject our estimated pollution-income relationship to various tests of robustness and find that, unlike earlier studies, our results are remarkably robust to changes in assumptions about estimation techniques.

Consequently, literacy and institutions were found to mitigate the level of environmental degradation. It implies that education influences changes in consumer preference for cleaner environment; and to that end, government institutions and civil society need to propagate more awareness campaign for environmental management. Similarly there is need to build strong and effective environmental regulatory framework, increases abatement measures and adoption of clean technologies.

\section{References}

Agras J., \& Chapman D. (1999). A Dynamic Approach to the Environmental Kuznets Curve Hypothesis, Ecological Economics, 28, 267-277

Alege P. O., \& Ogundipe A. A. (2013). Environmental quality and economic growth in Nigeria: A fractional cointegration approach". International Journal of Development and Sustainability, vol. 2 No. 2.

Al Sayed A. R. M., \& Sek S. K. (2013). Environmental Kuznets Curve: evidences from Developed and Developing Economies. Applied Mathematical Sciences, 7(33), 1081-1092

Baliamoune-Lutz, M. (2011). Growth by destination (where you export matters): Trade with China and growth in African Countries. African Development Review, 23(2), 202-218.

Berkerman, N. (1992) Economic growth and the environment: whose growth? Whose environment? World Development, 20(4), 481-496

Bhattari, M., \& Hammig, M. (2001). Institutions and the Environmental Kuznets Curve for

\footnotetext{
${ }^{21}$ A negative relationship between household income and pollution does not imply that increasing local income will automatically be associated with an improvement in local environmental quality because it may be cheaper to relocate to a less polluted area than to reduce local pollutions. Alternatively, households may lobby to relocate polluting industries to other areas, and local environmental quality improves at the expense of environmental quality elsewhere.
} 
America, Africa and Asia. World Development, 29(6), 995-1010.

Galeotti, M., Lanza, A, \& Pauli, F. (2006). Reassessing the Environmental Kuznets Curve for $\mathrm{CO}_{2}$ Emissions: A robustness exercise, Ecological Economics, 57(1), 157-163

Ciriacy-Wantrup S. V. (1963). Resource Conservation Economics and Policies Revised Edition, University of California, Revised Edition

Chapman D. (1993). Environment, Income and Environment in Southern Africa: An analysis of the Interaction of Environmental and Macro Economics", Cornell Institute for Social and Economic Research.

Chapman D., \& Thomas D. (1990). Equity and Effectiveness of Possible Carbon Dioxide Treaty Proposals: Contemporary Policy Issues. 8(3), 16-28, July.

Chapman D., \& Randolph B. (1991). Environmental Protection, Resource, Resource Depletion, and the Sustainability of Developing Country Agriculture. Economic Development and Cultural Change. 39, 723-737, July.

Coondoo, D., \& Dinda, S. (2002). Causality between Income and Emission: A country Group Specific Econometric Analysis, Ecological Economics, 40(3), 351-367

Cole, M. A. (2000). Air Pollution and 'Dirty' Industries: How and Why Does the Composition of Manufacturing Output Change with Economic Development? Environmental and Resource Economics, 17(1), 109-123.

Cole M. A. (2004). Trade, the Pollution Haven Hypothesis and the Environmental Kuznets Curve: Examining the linkages, Ecological Economics, 48, 71-81.

Cole, M. A., \& Elliott, R. J. R. (2003). Determining the Trade-Environment Composition Effect: The Role of Capital, Labor and Environmental Regulations, Journal of Environmental Economics and Management, 46(3), 363-83.

Cole M. A., Elliott R. J. R., \& Fredriksson, P. G. (2006). Endogenous pollution havens: does FDI influence environmental regulations? Scandinavian Journal of Economics, 108, 157-78.

Grossman, G., \& Krueger, A. (1991). Environmental Impacts of a North America Free Trade Agreement, Natural Bureau of Economy Research working paper No. 3194, Cambridge: NBER

Grossman, G. and Krueger, A.(1995). Economic growth and the environment", Quarterly Journal of Economics, 110, 353-77.

Halicioglu, F. (2009). An econometric study of CO2 emissions, energy consumption, income and foreign trade in Turkey, Energy Policy, 37(3), 1156-1164

Holtz-Eakin, D., \& Selden T. M. (1995). Stocking the fires? $\mathrm{CO}_{2}$ Emissions and Economic Growth. J. public Econ. 57, 85-101

Hollander J. M. (2003). The real environmental crisis: why poverty, not affluence, is the Environment's number one Enemy. Berkeley, Calif, University of California Press, 2003. 
Khanna N, (2002). The income elasticity of non-point source air pollutants: revisiting the environmental Kuznets curve, Economics Letters, 77, 387-392

Lee C, Chiu Y, \& Sun C. (2010). The Environmental Kuznets curve hypothesis for water pollution: Do regions matter? Energy Policy, 38, 12-23

Narayan, P. K., \& Smyth, R. (2007). A Panel Cointegration analysis of the demand for oil in the middle East, Energy Policy, 35(12), 6258-6265

Ogundipe, A. A., Alege, P. O., \& Ogundipe, O. M. (2014). Income Heterogeneity and Environmental Kuznets Curve in Africa. Journal of Sustainable Development 7(4), 165-180

Ogundipe, A. A., \& Akinyemi, O. (2014). Electricity consumption and Economic Development in Nigeria. http://dx.doi.org/10.2139/ssrn.2472463

Omotor, D. G., \& Orubu C.O. (2012). Searching for environmental Kuznets curve of some Basics in Africa. Department of Economics, Delta State University, Abraka, Nigeria

Orubu C. O, Omotor D. G., \& Awopegba P. O. (2009). Economic Growth and environmental quality: searching for environmental Kuznets curve in Africa". Paper presented at CSAE conference, University of Oxford, UK

Osabuohien E. S, Efobi U. R., \& Gitau C. M. (2004). Beyond the environmental Kuznets Curve in Africa: evidence from panel cointegration. Journal of Environmental Policy and Planning.

Panayotou T. (1993). Empirical tests and policy Analysis of environmental degradation at different stages of economic development. Working paper WP238, technology and employment programme. ILO, Geneva

Perrings, C. (1989). An Optimal Path to Extinction? Poverty and Resource Degradation in the Open Agrarian Economy. Journal of Development Economics, 30, 1-24.

Perrings, C. (1991). Incentives for the Ecologically Sustainable Use of Human and Natural Resources in the Drylands of Sub-Saharan Africa: A Review. Prepared for the International Labour Office, Geneva, Switzerland

Perman, R., \& Stern, D. I., (2003). Evidence from Panel Unit Root and Cointegration Test that the Environmental Kuznets Curve Does not Exist, Australian Journal of Agricultural and Resource Economics, 47(3), 325-347

Ruttan Vernon W. (1971). Technology and the Environment. AAEA Presidential Address, America, Journal of Agricultural Economics, 53, 707-717

Selden, T. M., \& Song, D. (1994). Environmental Quality and Development: Is there a Kuznet curve for air pollution? Journal of environmental Economics and Environmental management, 27(2), 147-162

Schmidheiny K., \& Basel U. (2011). Panel Data: Fixed and Random effects

Shafik, N., \& Bandyopadhyay S. (1992). Economic Growth and Environmental Quality: 


\section{Macrothink}

Environmental Management and Sustainable Development

ISSN 2164-7682

2015, Vol. 4, No. 2

Time Series and Cross Country Evidence. Background Paper for World Development Report 1992, the World Bank, Washington, D.C

Stanton, E. A. (2012). The Tragedy of Mal-distribution: Climate, Sustainability and Equity, Sustainability, 4(3), 394-411

Stern, D. (2004). The Rise and Fall of the Environmental Kuznets Curve, World Development, 32(8), 1419-1439

Stern, D. (2004). Economic Growth and Environmental Degradation: The Environmental Kuznets Curve and Sustainanble Development. World Development, 24(7), 1151-1160

Stern D. I., Common, M. S., \& Barbier, E. B. (1996). Economic Growth and Environmental degradation: the Environmental Kuznets Curve and Sustainable Development. World Dev. 24(7), 1151-1160

Suri, V., \& Chapman D. (1998). Economic Growth, Trade and Energy: Implications for the Environmental Kuznets Curve. Ecological Economics. Special Issue on the Environmental Kuznets Curve

Torres M., \& Boyce J. K (1998). Income, Inequality and Pollution: A reassessment of the Environmental Kuznets, Ecological Economics, 25(2), 195-208

Villanueva, I. A. (2012.). Introducing institutional variables in the environmental Kuznets curve: A Latin America study, in: Annals of the constantin Brancusi University of Targu Jiu, Economy Series, $\quad$ Issue $1 / 2012$. Available at http://www.utgjiu.ro/revista/ec/pdf/201201/G_ITALO_ARBULU_VILLANUEVA._pdf (accessed 2nd Feb. 2014)

Wycoff A. W., \& Rooop, J. M. (1994). The embodiment of Carbon in imports of manufactured products: Implications for international agreements on greenhouse gas emissions. Energy Policy, 22(3), 187-194

\section{Copyright Disclaimer}

Copyright for this article is retained by the author(s), with first publication rights granted to the journal.

This is an open-access article distributed under the terms and conditions of the Creative Commons Attribution license (http://creativecommons.org/licenses/by/3.0/). 